\title{
PROGRAM PENJAMINAN MUTU SEKOLAH (STUDI KASUS SDN 36 DAN SDIT AL FITYAH KOTA PEKANBARU)
}

\author{
Suheri ${ }^{1}$ \\ Zulfan Saam ${ }^{2}$ \\ Caska $^{2}$ \\ ${ }^{1}$ Post Graduate Student of Riau University \\ ${ }^{2}$ Lecturer of Education Management Study Programme PPs University of Riau
}

\begin{abstract}
The research aims to analyze the map quality, quality manual, quality assurance and SOP institutional quality assurance SDN 36 and SDIT Al Fityah city of Pekanbaru. Informants to be interviewed in this research is the principal and Vice Principal at SDN 36 and SDIT Al Fityah city of Pekanbaru. The instruments used are shaped intervie, observation and documentation. Data analysis which is used toexpose the data quality assurance program school case studies of SDN 36 and SDIT Al Fityah city of Soweto), used a qualitative analysis. The results showed that first, map quality SDN 36 and SDIT Al Fityah city of Pekanbaru were already attempting to carry out the task of drafting the program and evaluation of the quality of education the school mapping. Second, the guideline of quality SDN 36 and SDIT Al Fityah Pekanbaru minimum service standards. Third, quality assurance SDN 36 SOP and SDITAl Fityah Pekanbaru meets the standards and infrastructure customized SNPS and SPM. Fourth, institutional quality assurance SDN 36 and SDIT Al Fityah Pekanbaru refers to the institutional structure which guarantees the quality of staffing and are handled by the head of school.
\end{abstract}

Key words: quality assurance program; SDN 36 and SDIT Al Fityah

\begin{abstract}
Abstrak: Penelitian in bertujuan untuk menganalisis peta mutu, pedoman mutu, SOP penjaminan mutu dan kelembagaan penjaminan mutu SDN 36 dan SDIT Al Fityah Kota Pekanbaru. Informan untuk diwawancarai dalam penelitian ini adalah Kepala Sekolah dan Wakil Kepala Sekolah di SDN 36 dan SDIT Al Fityah Kota Pekanbaru. Instrumen yang digunakan berbentuk wawancara, observasi dan dokumentasi. Analisis data yang digunakan untuk memaparkan data program penjaminan mutu sekolah (Studi Kasus SDN 36 dan SDIT Al Fityah Kota Pekanbaru), digunakan analisis kualitatif. Hasil penelitian menunjukkan bahwa pertama, peta mutu SDN 36 dan SDIT Al Fityah Kota Pekanbaru sudah berupaya melaksanakan tugas penyusunan program dan evaluasi pemetaan mutu pendidikan sekolah. Kedua, pedoman mutu SDN 36 dan SDIT Al Fityah Kota Pekanbaru sesuai Standar Pelayanan Minimal. Ketiga, SOP penjaminan mutu SDN 36 dan SDIT Al Fityah Kota Pekanbaru memenuhi standar sarana dan prasarana disesuaikan SNP dan SPM. Keempat, kelembagaan penjaminan mutu SDN 36 dan SDIT Al Fityah Kota Pekanbaru mengacu pada struktur kelembagaan yang menjamin mutu ditangani oleh kepegawaian dan kepala sekolah.

Kata kunci: program penjaminan mutu ; SDN 36 and SDIT Al Fityah
\end{abstract}

\section{PENDAHULUAN}

Pendidikan bermutu merupakan sarana utama yang memberikan akses penting bagi upaya mencerdaskan kehidupan bangsa dan meraih kehidupan yang baik, maju, dan berkeadilan di masa depan. Dalam konteks ini, bukan sekadar pendidikan yang dapat memberikan kekuatan dan kekayaan intelektual (ilmu pengetahuan) namun juga menjadikan manusia Indonesia yang memiliki kemampuan berpikir dan olah nalar secara cerdas, melainkan juga pendidikan yang dapat memberikan bekal moral dan etika yang terpuji. Pendidikan bermutu diharapkan pula mampu mengembangkan potensi diri manusia Indonesia berikut melahirkan manusia-manusia kreatif, mandiri, dan beretos kerja tinggi. Pendidikan bermutu haruslah menjadi sarana yang dapat menyediakan dan memberikan bekal kehidupan (life skill) bagi setiap manusia Indonesia.

Pembangun pendidikan bermutu di Indonesia mesti mengacu pada prinsip-prinsip ideologi negara dan amanat konstitusi yang mempertimbangkan semangat zaman dan budaya bangsa. Lebih dari itu, pembangunan pendidikan bermutu juga mesti memperhitungkan dimensi manusia sebagai subyek yang memiliki kebutuhan lahir dan batin sekaligus dengan sungguh-sungguh.

Pendidikan bermutu dan/atau mutu tinggi pendidikan sesungguhnya tidak bisa diciptakan dalam tempo sekejap atau dicapai dengan cara-cara instant dan jalan pintas. Ia membutuhkan waktu dan proses yang cukup panjang serta juga kesabaran dan konsistensi kebijakan. Untuk mewujudkan pendidikan yang bermutu diperlukan keterlibatan segenap komponen bangsa, karena sangat disadari bahwa pendidikan nasional merupakan tanggung jawab bersama antara orang tua, pemerintah, dan masyarakat. Pendidikan bermutu menjadi tanggung jawab bersama dari berbagai pihak (quality is everybody's bussiness) serta bertumbuh menjadi budaya mutu. Pendidikan yang bermutu dimaknai sebagai layanan pendidikan yang memadai bagi semua warga negara sesuai dengan kebutuhan pendidikannya, termasuk mereka yang membutuhkan pendidikan khusus dan layanan khusus.

Sistem penjaminan mutu (quality assurance) pendidikan sesungguhnya tidaklah sama (atau sesuatu yang berbeda) dengan mutu pendidikan (quality of education) itu sendiri. Mutu pendidikan lebih sebagai wujud terbaik yang dihasilkan oleh proses pembelajaran optimal di satuan pendidikan. Jadi, mutu pendidikan berfokus pada kualitas sosok yang tercipta sesuai yang diharapkan. Sementara sistem penjaminan mutu pendidikan merupakan siklus manajemen dalam penyelenggaraan pendidikan yang meliputi kegiatan mengukur, mengevaluasi, dan mengawal mutu, menyangkut praktik dan tradisi akademik dan non akademik pada satuan pendidikan.

Sebuah satuan pendidikan dapat dikatakan memiliki tingkat mutu tertentu jika 
telah melewati proses audit oleh lembaga penjaminan mutu (internal dan eksternal). Dengan demikian, satuan pendidikan yang mengumumkan dirinya bermutu tinggi, sekolah terbaik, dan predikat lain belum bisa dipercaya begitu saja sebelum mendapat sertifikat mutu dari organisasi penjaminan mutu pendidikan yang legitimate, profesional, dan terpercaya.

Sistem penjaminan mutu pendidikan menjadi penting untuk memantau dan memastikan setiap program/jurusan dan institusi satuan pendidikan diselenggarakan sesuai standar mutu pendidikan. Citra pendidikan juga turut terjaga dengan adanya kegiatan penjaminan mutu (internal dan eksternal) yang dilakukan oleh lembaga independen yang memiliki perangkat kerja yang jelas dan terbuka untuk diakses publik. Oleh karena itu, sangatlah dibutuhkan aturan main yang jelas, tegas, serta memiliki payung hukum yang kuat mengenai sistem penjaminan mutu pendidikan.

SDN 36 Kota Pekanbaru atau dikenal dengan sebutan SD Teladan, berhasil menambah rekor. Sekolah yang dipimpin Kepala Sekolah Zulkarnaini tersebut meraih juara umum Festival Lomba Seni Siswa Nasional (FLS2N) tingkat Kota Pekanbaru.

Selain itu pelaksanaan program penjaminan mutu penulis merujuk pada salah satu SD Swasta Kota Pekanbaru yaitu SDIT Al Fityah Kota Pekanbaru yang merupakan sekolah dengan kategori unggul. Kategori unggul menjadi pilihan peneliti, karena sekolah pada kategori ini merupakan Sekolah Dasar Islam Terpadu yang ada di daerah Kota Pekanbaru. Alasan pemilihan SDIT Al Fityah Kota Pekanbaru, hal ini dikarenakan sekolah ini selain berada pada level sekolah dengan kategori unggul juga memiliki lokasi yang strategis sehingga memungkinkan penulis untuk dapat meningkatkan mobilitas, sehingga memperlancar pelaksanaan kegiatan penelitian.

Sekolah Islam berusaha menyiapkan lulusan yang memiliki kemampuan sains dan tekhnologi handal dan dikawal oleh keimanan dan ketakwaan melalui bentuk lembaga pendidikan terpadu seperti Sekolah Dasar Islam Terpadu (SD-IT) dan Sekolah Menengah Islam Terpadu (SMP-IT) dan lain sebagainya. Apalagi, output yang dihasilkan Sekolah Islam Terpadu tak kalah dengan sekolah-sekolah unggulan yang selama ini terkesan hanya didominasi sekolah-sekolah non-Muslim.

Begitu bertumbuhkembangnya Sekolah Dasar Islam Terpadu di Pekanbaru. Orang tua menganggap SDIT sebagai pilihan untuk pendidikan anak-anak mereka. Biaya yang mahal tidak menjadi persoalan karena harapan bahwa sekolah dapat memberikan pendidikan yang terbaik bagi anak-anak mereka. Perkembangan SDIT di Pekanbaru terus meningkat sampai satu-dua tahun terakhir.

Berdasarkan latar belakang masalah dan fenomena yang ditemukan dalam proses Penjaminan Mutu Sekolah Dasar Negeri, maka yang menjadi fokus dalam penelitian ini adalah Penjaminan Mutu Sekolah (Studi Kasus SDN 36 dan SDIT Al Fityah Kota Pekanbaru). Sedangkan sebagai subfokus dalam penelitian ini adalah: (1) Peta mutu sekolah, (2) Pedoman mutu sekolah, (3) SOP penjaminan mutu sekolah, dan (4) Kelembagaan penjaminan mutu sekolah.

\section{Jenis Penelitian}

\section{METODOLOGI PENELITIAN}

Penelitian ini menggunakan pendekatan deskriptif. Penelitian deskriptif adalah penelitian yang hanya melibatkan satu variabel pada satu kelompok, tanpa penelitian dilakukan atas satu kelompok dalam hal satu variabel menghubungkan dengan variabel lain atau membandingkan dengan kelompok lain.

\section{Tempat dan Waktu Penelitian}

Tempat penelitian ini diadakan pada SDN 36 Pekanbaru beralamat di jalan Hangtuah nomor 59 Kelurahan Rintis Kecamatan Limapuluh Kota Pekanbaru dan di SDIT Al Fityah Pekanbaru beralamat di jalan Karya Kelurahan Tuah Karya Panam Kota Pekanbaru. Waktu pelaksanaan penelitian dimulai sejak bulan Juni sampai dengan bulan Oktober 2015.

\section{Informan Penelitian}

Sebagai informan kunci (untuk diwawancarai atau diobservasi) adalah Kepala Sekolah dan Wakil Kepala Sekolah di SDN 36 dan SDIT Al Fityah Kota Pekanbaru, beserta beberapa guru yang terlibat dalam program penjaminan mutu.

\section{Teknik Pengumpulan Data}

Adapun teknik pengumpulan data dalam penelitian iniadalah sebagai berikut:

1. Wawancara

Pengumpulan data dengan melakukan tanya jawab yang dijawab secara lisan oleh responden tentang program penjaminan mutu sekolah yaitu Kepala Sekolah dan Wakil Kepala Sekolah di SDN 36 dan SDIT Al Fityah Kota Pekanbaru.

2. Observasi

Observasi adalah kegiatan pengumpulan data dengan melakukan penelitian langsung terhadap kondisi lingkungan objek penelitian, seperti lokasi, sarana dan prasarana sekolah, ruang belajar, sarana pendidikan, dan pelaksanaan pembelajaran di sekolah, sehingga dapat di gambarkan secara jelas tentang kondisi objek penelitian tersebut.

3. Dokumentasi

Dokumentasi merupakan catatan peristiwa yang sudah berlalu. Dokumen biasa berbentuk tulisan, gambar atau karya dari seseorang. Dokumentasi diperlukan untuk memperkuat data wawancara dan observasi seperti dokumen kurikulum sekolah, modul, brosur, dan foto berbagai aktivitas yang berkaitan dengan program penjaminan mutu sekolah. 


\section{Teknik Analisa Data}

Untuk memaparkan data program penjaminan mutu sekolah (Studi Kasus SDN 36 dan SDIT A1 Fityah Kota Pekanbaru), digunakan analisis kualitatif. Dalam penelitian ini data dianalisis dengan menggunakan langkah-langkah yang dianjurkan oleh Miles dan Huberman (1992) yaitu: (1) mereduksi data, (2) menyajikan data, (3) menyimpulkan dan melakukan verifikasi.

\section{A. Peta Mutu Sekolah}

\section{HASIL DAN PEMBAHASAN}

Upaya penjaminan dan peningkatan mutu pendidikan sulit dilepaskan keterkaitannya dengan manajemen mutu, semua fungsi manajemen dijalankan semaksimal mungkin agar dapat memberikan layanan yang sesuai atau melebihi Standar Nasional Pendidikan yang ditetapkan BSNP. Namun, tidak semua satuan pendidikan dan pihak yang terkait, dapat memahami dan merniliki komitmen dalam memenuhi SNP tersebut.

Berdasarkan data dan informasi dari hasil wawancara penulis dengan informan dapat dianalisis bahwa di SDN 36 Kota Pekanbaru sudah berupaya melaksanakan tugas penyusunan program dan evaluasi pemetaan mutu pendidikan sekolah agar sesuai dengan program yang telah disusun sebelumnya bersama guru dan kepala sekolah. Kepala sekolah/guru melaksanakan tugas penyusunan program dan evaluasi pemetaan mutu pendidikan pada program Penjaminan Mutu Sekolah di sekolah ini. Setiap bulan ada rapat kerja guru, dilaksanakan satu minggu sebanyak 3 hari. Pertemuan untuk mengevaluasi yang sudah dijalankan dan menyusun program untuk masa yang akan datang pada bagian kurukulum, bagian kesiswaan, dan bagian sarana dan humas. Program diadakan melalui guru sesuai dengan struktur mulai dari kepala sekolah terus ke guru, sesuai dengan program yang sudah disepakati seluruh majelis guru.Merasa punya dan sekolah tidak pernah melaporkkan ke LPMP. Guru atau Kepala Sekolah pasti ada menyusun pemetaan mutu pendidikan di sekolah masing-masing.

Berdasarkan data dan informasi dari hasil wawancara penulis dengan informan dapat dianalisis bahwa di SDN 36 Kota Pekanbaru teknis yang kami laksanakan sehubungan dengan pelaksanaan pemetaan mutu pendidikan berupa mendatangkan nara sumber melalui KKG. Guru belum diberi pengarahan oleh kepala sekolah, mendatangkan nara sumber melalui KKG. Sekolah memiliki beberapa program yaitu peningkatan kompetensi guru yang diisi oleh yayasan disertai diklat, ada yang diundang dari luar, dan melalui K3S. Peningkatan bakat siswa, seperti yang diwajibkan yaitu renang, pramuka, kesenian, taekwando, O2SN sudah dinasional, olimpiade matematika di Provinsi. SDIT Al Fityah Pekanbaru dalam harian, guru menghendel dari program pemetaan, sekolah berfungsi sebagai pengontrol bagaimana pelaksanaan dari program tersebut.

Berdasarkan data dan informasi dari hasil wawancara penulis dengan informan LPMP Kota Pekanbaru dapat dianalisis bahwa LPMP mulai dari 2009 dibantu mengisi atau mengiring silabus sekolah, dinas melanjutkannya lagi kemudian terakhir tahun 2013. Ada bermacam-macam mulai dari pertama, hasil ujian nasional dan berapa nilai anak tertinggi dan terendah. Berapa orang di sekolah itu diterima atau melanjutkan ke sekolah favorit. Dari kejuaraan dan perlombaan yang diikuti siswa baik tingkat kecamatan, kabupaten, atau tingkat nasional baik dari segi mata pelajara dan yang lainnya.

Berdasarkan data dan informasi dari hasil wawancara penulis dengan informan dapat dianalisis bahwa di SDN 36 Kota Pekanbaru dalam melaksanakan pengelolaan dan pengembangan informasi mutu pendidikan kami telah melakukan kegiatan yang efektif dalam meniingkatkan disiplin guru dalam mengajar, disiplin dalam kehadiran di sekolah, menyediakan guru alternatif jika ada guru yang berhalangan hadir di sekolah, menyusun mata pelajaran tambahan dan mempersiapkan administrasi guru. Peningkatan disiplin guru dalam mengajar, datang atau keluar sekolah tepat waktu, mencari guru pengganti apabila guru tidak masuk, penyusunan mata pelajaran tambahan terutama kelas, mempersiapkan administrasi guru.

Berdasarkan data dan informasi dari hasil wawancara penulis dengan informan dapat dianalisis bahwa di SDIT Al Fityah Pekanbaru sudah web site sendiri untuk memberi informasi, papan infomasi sekolah, pesan telefon ananda, POMGKP dilaksanakan orang tua dengan guru memberi informasi, diadakan sekali setahun. Sudah disampaikan kepada guru, kendala yang terjadi diadakan rapat untuk mencari jalan keluarnya.

Berdasarkan data dan informasi dari hasil wawancara penulis dengan informan LPMP Kota Pekanbaru dapat dianalisis bahwa sekolah sekarang sudah mempunyai operator sekolah maka sekolah mengisi laporan dan pihak LPMP tidak lagi mengirim berkas-berkas untuk sekolah. Melalui pelatihan dan bimbingan teknis (Bimtek).

Berdasarkan data dan informasi dari hasil wawancara terhadap informan tentang pelaksanaan supervisi satuan pendidikan anak usia dini, pendidikan dasar, dan pendidikan menengah pada jalur pendidikan formal mengenai hasil output seperti apa dalam pelaksanaan supervisi satuan pendidikan dasar, dan pendidikan menengah pada jalur pendidikan formal

Berdasarkan data dan informasi dari hasil wawancara penulis dengan informan dapat dianalisis bahwa di SDN 36 Kota Pekanbaru Output dalam pelaksanaan supervisi satuan pendidikan dasar, dan pendidikan mendapat hasil prestasi yang terbaik bidang akademis maupun bidang kesenian. Mendapat hasil prestasi yang baik-baik bidang, akademis maupun bidang kesenian, ketentuan untuk usia dini berdasarkan keputusan Perwako.

Berdasarkan data dan informasi dari hasil wawancara penulis dengan informan dapat dianalisis bahwa di SDIT Al Fityah Pekanbaru tingkat kepercayaan orang tua kepada sekolah sangat tinggi. Tetap memiliki karakter, program mutu yang digulingkan tetap bertahap.

Perlu diperhatikan bahwa proses penjaminan mutu hanya akan berhasil jika semua pihak yang bertanggung jawab dalam proses pendidikan ikut berperan untuk memberikan layanan terbaik. Oleh sebab itu, proses penjaminan mutu harus dilaksanakan atas dasar prinsip-prinsip sebagai berikut, mutu bukan hanya menjadi tanggung jawab pimpinan melainkan menjadi tanggung jawab semua orang dalam organisasi, melakukan tindakan yang benar pada tahapan pertama sehingga dapat mencegah terjadinya kesalahan. Menunda pekerjaan dapat berakibat fatal pada seluruh proses manajemen. Oleh sebab itu, pencegahan lebih baik dibanding dengan menanggulangi dan memperbaiki kesalahan, dan keberhasilan melaksanakan manajemen pada suatu proses sangat ditentukan oleh iklim organisasi, yakni komunikasi 
dan tim kerja yang kompak. Melalui komunikasi dan kerja sama, semua orang mengetahui apa yang seharusnya dikerjakan, bagaimana mengerjakan, kapan Waktu yang tepat, di mana dan dengan siapa harus berhubungan/berkomunikasi.

Berdasarkan data dan informasi dari hasil wawancara penulis dengan informan LPMP Kota Pekanbaru dapat dianalisis bahwa sehubungan hal di atas selama ini LPMP tidak ada lagi menerima hasil output yang dimaksudkan. Ada laporan berapa siswa yang lulus ujian nasional.

Berdasarkan data dan informasi dari hasil wawancara penulis dengan informan dapat dianalisis bahwa di SDN 36 Kota Pekanbaru hasil yang diperoleh dari hasil kerjasama di bidang pemetaan mutu pendidikan dengan menjalin kerja sama dengan dinas pendidikan untuk mengembangkan mutu pendidikan diiutamakan pada bidang pengembangan kesenian berbudaya Melayu. Kerja sama dengan dinas saja, siswa yang telah lambat dapat membimbing adek-adeknya dalam bidang kesenian.

Berdasarkan data dan informasi dari hasil wawancara penulis dengan informan dapat dianalisis bahwa di SDIT Al Fityah Pekanbaru ada beberapa kerja sama dengan pihak lain dalam bidang adwiyata, kerja sama dengan pihak bank, kerja sama dengan kesehatan, kerja sama dengan pihak sampah, kerja sama dengan LFP (Forum Lingkar Pena), bergerak di bidang menulis, bergerak di bidang taekwando. Sekolah melibatkan orang tua, bagaimana program-program, karakter-karakter anak, sekolah mengkomunikasikan kepada orang tua, maka orang tua, kerja sama dengan guru sangat mendukung.

Berdasarkan data dan informasi dari hasil wawancara penulis dengan informan LPMP Kota Pekanbaru dapat dianalisis bahwa tidak ada karena hubungan LPMP dengan sekolah tidak ada.

Berdasarkan data dan informasi dari hasil wawancara penulis dengan informan tentang peta mutu sekolah dapat dianalisis bahwa di SDN 36 Kota Pekanbaru sudah berupaya melaksanakan tugas penyusunan program dan evaluasi pemetaan mutu pendidikan sekolah agar sesuai dengan program yang telah disusun sebelumnya bersama guru dan kepala sekolah.

Penjaminan mutu adalah susunan proses yang saling berkaitan untuk mengumpulkan, menganalisis dan melaporkan data mengenai kinerja dan mutu tenaga kependidikan, program pendidikan dan institusi pendidikan (sekolah dasar dan menengah). Penjaminan mutu mengarah pada peningkatan mutu. Proses penjaminan mutu mencakup bidang yang akan dicapai beserta prioritas pengernbangan, dengan menyajikan data perencanaan yang didasarkan pada bukti serta pengambilan keputusan, dan mendukung budaya peningkatan yang berkelanjutan.

Berdasarkan data dan informasi dari hasil wawancara penulis dengan informan dapat dianalisis bahwa di SDN 36 Kota Pekanbaru teknis yang kami laksanakan sehubungan dengan pelaksanaan pemetaan mutu pendidikan berupa mendatangkan nara sumber melalui KKG. Guru belum diberi pengarahan oleh kepala sekolah, mendatangkan nara sumber melalui KKG. Sekolah memiliki beberapa program yaitu peningkatan kompetensi guru yang diisi oleh yayasan disertai diklat, ada yang diundang dari luar, dan melalui K3S. Peningkatan bakat siswa, seperti yang diwajibkan yaitu renang, pramuka, kesenian, taekwando, O2SN sudah dinasional, olimpiade matematika di Provinsi.

SDIT Al Fityah Pekanbaru dalam harian, guru menghendel dari program pemetaan, sekolah berfungsi sebagai pengontrol bagaimana pelaksanaan dari program tersebut.

Berdasarkan data dan informasi dari hasil wawancara penulis dengan informan LPMP Kota Pekanbaru dapat dianalisis bahwa LPMP mulai dari 2009 dibantu mengisi atau mengiring silabus sekolah, dinas melanjutkannya lagi kemudian terakhir tahun 2013. Ada bermacam-macam mulai dari pertama, hasil ujian nasional dan berapa nilai anak tertinggi dan terendah. Berapa orang di sekolah itu diterima atau melanjutkan ke sekolah favorit. Dari kejuaraan dan perlombaan yang diikuti siswa baik tingkat kecamatan, kabupaten, atau tingkat nasional baik dari segi mata pelajara dan yang lainnya.

Berdasarkan data dan informasi dari hasil wawancara penulis dengan informan dapat dianalisis bahwa di SDN 36 Kota Pekanbaru dalam melaksanakan pengelolaan dan pengembangan informasi mutu pendidikan kami telah melakukan kegiatan yang efektif dalam meniingkatkan disiplin guru dalam mengajar, disiplin dalam kehadiran di sekolah, menyediakan guru alternatif jika ada guru yang berhalangan hadir di sekolah, menyusun mata pelajaran tambahan dan mempersiapkan administrasi guru. Peningkatan disiplin guru dalam mengajar, datang atau keluar sekolah tepat waktu, mencari guru pengganti apabila guru tidak masuk, penyusunan mata pelajaran tambahan terutama kelas, mempersiapkan administrasi guru.

Berdasarkan data dan informasi dari hasil wawancara penulis dengan informan dapat dianalisis bahwa di SDIT Al Fityah Pekanbaru sudah web site sendiri untuk memberi informasi, papan infomasi sekolah, pesan telefon ananda, POMGKP dilaksanakan orang tua dengan guru memberi informasi, diadakan sekali setahun. Sudah disampaikan kepada guru, kendala yang terjadi diadakan rapat untuk mencari jalan keluarnya.

Berdasarkan data dan informasi dari hasil wawancara penulis dengan informan LPMP Kota Pekanbaru dapat dianalisis bahwa sekolah sekarang sudah mempunyai operator sekolah maka sekolah mengisi laporan dan pihak LPMP tidak lagi mengirim berkas-berkas untuk sekolah. Melalui pelatihan dan bimbingan teknis (Bimtek).

Berdasarkan data dan informasi dari hasil wawancara penulis dengan informan dapat dianalisis bahwa di SDN 36 Kota Pekanbaru Output dalam pelaksanaan supervisi satuan pendidikan dasar, dan pendidikan mendapat hasil prestasi yang terbaik bidang akademis maupun bidang kesenian. Mendapat hasil prestasi yang baik-baik bidang, akademis maupun bidang kesenian, ketentuan untuk usia dini berdasarkan keputusan Perwako.

Berdasarkan data dan informasi dari hasil wawancara penulis dengan informan dapat dianalisis bahwa di SDIT Al Fityah Pekanbaru Tingkat kepercayaan orang tua kepada sekolah sangat tinggi. Tetap memiliki karakter, program mutu yang digulingkan tetap bertahap.

Berdasarkan data dan informasi dari hasil wawancara penulis dengan informan LPMP Kota Pekanbaru dapat dianalisis bahwa sehubungan hal di atas selama ini LPMP tidak ada lagi menerima hasil output yang dimaksudkan. Ada laporan berapa siswa yang lulus ujian nasional.

Berdasarkan data dan informasi dari hasil wawancara penulis dengan informan dapat dianalisis bahwa di SDN 36 Kota Pekanbaru hasil yang diperoleh dari hasil kerjasama di bidang pemetaan mutu pendidikan dengan menjalin kerja sama dengan dinas pendidikan untuk mengembangkan mutu pendidikan diiutamakan pada bidang pengembangan kesenian berbudaya Melayu. Kerja sama dengan 
dinas saja, siswa yang telah lambat dapat membimbing adek-adeknya dalam bidang kesenian.

Berdasarkan data dan informasi dari hasil wawancara penulis dengan informan dapat dianalisis bahwa di SDIT Al Fityah Pekanbaru ada beberapa kerja sama dengan pihak lain dalam bidang adwiyata, kerja sama dengan pihak bank, kerja sama dengan kesehatan, kerja sama dengan pihak sampah, kerja sama dengan LFP (Forum Lingkar Pena), bergerak di bidang menulis, bergerak di bidang taekwando. Sekolah melibatkan orang tua, bagaimana program-program, karakter-karakter anak, sekolah mengkomunikasikan kepada orang tua, maka orang tua, kerja sama dengan guru sangat mendukung.

Berdasarkan data dan informasi dari hasil wawancara penulis dengan informan LPMP Kota Pekanbaru dapat dianalisis bahwa tidak ada karena hubungan LPMP dengan sekolah tidak ada.

Berdasarkan data dan informasi dari hasil wawancara penulis dengan informan dapat dikatakan LPMP Kota Pekanbaru tidak lagi menerima laporan tentang evaluasi pelaksanaan penjaminan mutu sekolah karena laporannya sudah dikelola langsung oleh Dinas Pendidikan Kota Pekanbaru.

\section{Pedoman Mutu Sekolah}

Standar Nasional Pendidikan berfungsi sebagai dasar dalam perencanaan, pelaksanaan, dan pengawasan pendidikan dalam rangka mewujudkan pendidikan nasional yang bermutu. Standar Nasional Pendidikan bertujuan menjamin mutu pendidikan nasional dalam rangka mencerdaskan kehidupan bangsa dan membentuk watak serta peradaban bangsa yang bermartabat.

Berdasarkan data dan informasi dari hasil wawancara penulis dengan informan dapat dianalisis bahwa di SDN 36 Kota Pekanbaru memang sudah ada. SDN 36 Kota Pekanbaru teknis yang dilaksanakan dalam pelaksanaan Standar Pelayanan Minimal (SPM) dalam program Penjaminan Mutu Sekolah mengadakan pelajaran tambahan khusus untuk siswa, meningkatkan kompetensi guru dengan berbagai pelatihan. Ada pelajaran tambahan khusus kelas 6 yang dilaksanakan 4 kali dalam 1 minggu, meningkatkan kompetensi guru melalui pelatihan-pelatihan.

Berdasarkan data dan informasi dari hasil wawancara penulis dengan informan dapat dianalisis bahwa di SDIT Al Fityah Pekanbaru jumlah siswa perkelas lebih kurang 30 orang, karena sudah sesuai dengan ukuran kelas yang ada, lapangan sekolaah yang kurang luas, posisi guru sudah memenuhi (S1 semua), jumlah siswa dan guru sudah memenuhi, fasilitas kelas bisa terpenuhi, alat peraga PBM memenuhi standar. Program-program dipastikan mengacu pada SPM, tercapai SPM dilibatkan semua guru.

Berdasarkan data dan informasi dari hasil wawancara penulis dengan informan LPMP Kota Pekanbaru dapat dianalisis bahwa ada, mereka juga mengacu pada SPM dan SNP. Standar Pelayanan Minimal (SPM) mengenai teknis seperti apa yang dilaksanakan dalam pelaksanaan Standar Pelayanan Minimal (SPM) dalam program Penjaminan Mutu Sekolah.

Berdasarkan data dan informasi dari hasil wawancara penulis dengan informan dapat dianalisis bahwa di SDIT Al Fityah Pekanbaru diawali pertama pendidik harus sarjana, jumlah siswa tidak ada lebih 30 siswa, PBM memenuhi anggaran sekolah dan yayasan. Aplikatif lebih kepada siswa dimana di lapangan, memberikan pelayanan kepada siswa, kemudian pelayanan kepada orang tua.

Berdasarkan data dan informasi dari hasil wawancara penulis dengan informan LPMP Kota Pekanbaru dapat dianalisis bahwa berusaha menjamin mutu guru, kelulusan siswa, memperbaiki PBM sekolah dan itu dilaksanakan di sekolah dari berbagai program. Sesuai dengan pelaksanaan 8 standar pendidikan.

Berdasarkan data dan informasi dari hasil wawancara penulis dengan informan dapat dianalisis bahwa di SDN 36 Kota Pekanbaru output yang dicapai dalam pelaksanaan pedoman mutu sekolah sudah memuaskan, hampir semua siswa yang lulus dapat diterima di sekolah negeri dengan prestasi yang memuaskan. Hasil yang sangat memuaskan, minimal dapat diterima di sekolah negeri, menaikkan rangking sekolah dan mutu sekolah.

Berdasarkan data dan informasi dari hasil wawancara penulis dengan informan dapat dianalisis bahwa di SDIT Al Fityah Pekanbaru prestasi siswa, setiap tahun memiliki beberapa prestasi, lulusan siswa rata-rata cenderung ke sekolah islam yang hapalan Alqur'an, mengarah kepada Islam, mempunyai target yang selalu meningkat. Program-program minat siswa sangat banyak, hasil dari standar-standar yang diberikan sekolah.

Berdasarkan data dan informasi dari hasil wawancara penulis dengan informan LPMP Kota Pekanbaru dapat dianalisis bahwa lebih memperbaiki PBM di kelas, satgas pada sekolah sangat terbatas. Sesuai dengan pelaksanaan 8 standar dan sesuai juga dengan SPM.

\section{Standar Operasional Prosedur Mutu Sekolah}

Berdasarkan data dan informasi dari hasil wawancara penulis dengan informan dapat dianalisis bahwa di SDN 36 Kota Pekanbaru usaha dalam melaksanakan SOP Mutu Sekolah dalam memenuhi standar sarana dan prasarana. Diperoleh dari berbagai sumber baik dari dinas maupun bantuan orang tua sehingga sarana dan prasarana yang diadakan sudah cukup baik. SDN 36 Kota Pekanbaru sebagian besar dapat, pengadaan OHP pertingkat kelas, dibeli sebagian dari bantuan dinas, sebagian lagi dari dana sekolah, dari orang tua murid langsung, seperti OHP, kipas, dispenser.

Berdasarkan data dan informasi dari hasil wawancara penulis dengan informan dapat dianalisis bahwa di SDIT Al Fityah Pekanbaru dalam pembangunan besar mungkin ditangani oleh pemerintah/yayasan, sedang sebab ringan masih bisa dilakukan oleh sekolah itu sendiri. Sekolah dengan yayasan harus mendapatkan peretujuan dengan yaayasan, yayasan berperan sangat penting, rapat antara yayasan dengan kepala sekolah, kemudian kepala sekolah ke guru yang bersangkutan.

Kebijakan penjaminan mutu pendidikan merupakan tanggung jawab bersama dari berbagai pihak sehingga diperlukan komitmen dan pemahaman yang sama dalam pelaksanaan penjaminan mutu pendidikan.

Berdasarkan data dan informasi dari hasil wawancara penulis dengan informan LPMP Kota Pekanbaru dapat dianalisis bahwa ada, mereka juga mengacu pada SPM dan SNP. Sesuai dengan SOP standar sarana dan prasarana sekolah masing-masing.

Berdasarkan data dan informasi dari hasil wawancara penulis dengan informan dapat dianalisis bahwa di SDN 36 Kota Pekanbaru diperoleh dari dana komite sekolah, dari donatur orang tua siswa yang mampu, dari dinas kota/provinsi. SDN 36 Kota Pekanbaru memperoleh dana dari komite sekolah, 
dari donatur orang tua siswa yang mampu, dari dinas kota/provinsi. SDN 36 Kota Pekanbaru disesuaikan SNP dan SPM.

Berdasarkan data dan informasi dari hasil wawancara penulis dengan informan dapat dianalisis bahwa di SDIT Al Fityah Pekanbaru melalui wawancara dan seleksi guru apa sudah memenuhi, ada melalui tes IQ, dan ada masa training dan kriteria penerimaan guru, kontrak, kontrak (trainning) sesuai kemampuan dimiliki, pendidikan terendah adalah S1, kinerja guru sangat menentukan.

Berdasarkan data dan informasi dari hasil wawancara penulis dengan informan LPMP Kota Pekanbaru dapat dianalisis bahwa mereka minta ke dinas, menambah guru, menggunakan dana cabinet. bahwa bagi guru yang belum S1 dianjurkan untuk melanjutkan pendidikan, bagi guru yang belum paham mengikuti Diklat atau pelatihan tentang penilaian, evaluasi, media pembelajaran, bagi guru yang belum mengikuti tenaga kepustakaan.

Berdasarkan data dan informasi dari hasil wawancara penulis dengan informan dapat dianalisis bahwa di SDIT Al Fityah Pekanbaru gaji hanya dikeluarkan dari yayasan saja dan SDIT Al Fityah Pekanbaru yang dilihat oleh yayasan sudah sesuai dengan SNP programnya sudah sama dengan pemerintah, dana dari yayasan yang sudah ada.

Berdasarkan data dan informasi dari hasil wawancara penulis dengan informan LPMP Kota Pekanbaru dapat dianalisis bahwa tidak tahu karena itu sudah merupakan otoriter sekolah yang bersangkutan dan kepala sekolah melaksanakan pembiasaan sekolah.

\section{Kelembagaan Penjaminan Mutu Sekolah}

EDS dikembangkan sejalan dengan sistem penjaminan mutu pendidikan,khususnya yang terkait dengan perencanaan pengembangan sekolah dan manajemen berbasis sekolah. Pelaksanaan EDS terkait dengan praktek dan peran kelembagaan yang memang sudah berjalan, seperti manajemen berbasis sekolah, perencanaan pengembangan sekolah, akreditasi sekolah, implementasi SPM dan SNP, peran LPMP/BDK, peran pengawas, serta manajemen pendidikan yang dilakukan oleh pemerintahan provinsi dan kabupaten/kota, dan Rencana Pembangunan Nasional Bidang Pendidikan, Renstra Kemendikbud, dan Renstra Kemenag.

SDN 36 Kota Pekanbaru teknis yang dilaksanakan oleh pejabat penjaminan mutu merujuk pada tugas dan fungsi masing-masing bidang sesuai dengan tupoksi masing-masing.

Berdasarkan data dan informasi dari hasil wawancara penulis dengan informan dapat dianalisis bahwa di SDIT Al Fityah Pekanbaru struktur kelembagaan sudah sesuai dengan bidang masing-masing dimulai dari yayasan yang menjamin mutu ditangani oleh kepegawaian dan kepala sekolah baru ke guru. LPMP Kota Pekanbaru dapat dianalisis bahwa ada terutama untuk sekolah-sekolah yang ikut serta dalam RBI yang dikelola oleh LPMP.

Berdasarkan data dan informasi dari hasil wawancara penulis dengan informan dapat dianalisis bahwa di SDIT Al Fityah Pekanbaru ada rapat pembahasan program, dilaksanakan dan dievaluasi atau dikontrol pelaksanaannya., melalui rapat yayasan kepegawaian, kepala sekolah.

Berdasarkan data dan informasi dari hasil wawancara penulis dengan informan LPMP Kota Pekanbaru dapat dianalisis bahwa yang dilakukan adalah program-program yang terdapat dalam anggaran di LPMP.

Berdasarkan data dan informasi dari hasil wawancara penulis dengan informan dapat dianalisis bahwa di SDN 36 Kota Pekanbaru output yang dihasilkan dalam pelaksanaan hak dan kewajiban kelembagaan sekolah untuk optimalisasi pencapaian target prestasi yang direncanakan dari semua bidang untuk peningkatan mutu sekolah. Dapat menjalankan tugas pihak masing mendapatkan hak insentif dari yang lain, dapat melaksanakan tugas sesuai dengan apa yang diberikan oleh kepala sekolah, guru dapat meningkatkan mutu sekolah.

Berdasarkan data dan informasi dari hasil wawancara penulis dengan informan dapat dianalisis bahwa di SDIT Al Fityah Pekanbaru bisa melaksanakan program yang telah disusun sekolah lebih meningkatkan prorgam yang dilaksanakan. Keberadaan lembaga atau yayasan melaksanakan program penjaminan mutu, guru mempunyai daya tahan sesuai dengan kelembagan yayasan.

Berdasarkan data dan informasi dari hasil wawancara penulis dengan informan LPMP Kota Pekanbaru dapat dianalisis bahwa jika terkait dengan program di LPMP sekolah melaksanakan SOP sesuai dengan di LPMP biasanya ada dana untuk sekolah atau hanya diberikan bimbingan berbentuk teknis.

Tujuan akhir dari penjaminan mutu pendidikan adalah tingginya kecerdasan kehidupan manusia dan bangsa sebagaimana dicita-citakan oleh Pembukaan Undang-undang Dasar Negara Republik Indonesia Tahun 1945 yang dicapai melalui penerapan SPMP.

\section{SIMPULAN}

Berdasarkan temuan penelitian yang telah dijabarkan dapat disimpulkan bahwa:

a. Sekolah SDN 36 Pekanbaru sudah berupaya melaksanakan tugas penyusunan program dan evaluasi pemetaan mutu pendidikan sekolah dengan menjalin kerja sama dengan dinas pendidikan untuk mengembangkan mutu pendidikan diiutamakan pada bidang pengembangan kesenian berbudaya Melayu.

b. Sekolah SDIT Al Fityah Kota Pekanbaru dalam harian guru mengelola dari program pemetaan, sekolah berfungsi sebagai pengontrol bagaimana pelaksanaan dari program, beberapa kerja sama dengan pihak lain dalam bidang adwiyata, dengan pihak bank, dengan kesehatan, dengan Forum Lingkar Pena.

c. SDN 36 Pekanbaru dalam pelaksanaan pedoman mutu sekolah sudah sesuai Standar Pelayanan Minimal dengan prestasi yang memuaskan.

d. SDIT Al Fityah Kota Pekanbaru sudah melaksanakan program dengan mengacu pada SPM dengan melibatkan guru, orang tua dan pemerintah.

e. SDN 36 Pekanbaru berusaha dalam melaksanakan SOP Mutu Sekolah dalam memenuhi standar sarana dan prasarana disesuaikan SNP dan SPM. 
f. SDIT Al Fityah Kota Pekanbaru dalam pelaksanaan SOP sudah sesuai dengan SNP programnya sudah sama dengan pemerintah

g. SDN 36 Pekanbaru dalam kelembagaan penjaminan mutu sekolah sudah mengacu pada struktur kelembagaan yang ada sesuai dengan bidang masing-masing

h. SDIT Al Fityah Pekanbaru struktur kelembagaan sudah sesuai dengan bidang masingmasing dimulai dari yayasan yang menjamin mutu ditangani oleh kepegawaian dan kepala sekolah baru ke guru

\section{DAFTAR PUSTAKA}

AB. Musyafa' Fathoni. 2009. Peningkatan Kualitas Pendidikan Melalui Sistem Penjaminan Mutu Studi Multi Situs di SD Al Falah Tropodo 2 Sidoarjo. SDIT Bina Insani Kediri. dan SDIT Al Hikmah Blitar. Disertasi. Program Pascasarjana UM. 2009.

Agus wasisto Dwi Doso Warso 2014. Penjaminan Mutu Pelaksanaan Pengawasan dalam Pembelajaran di Madrasah Ibtidaiyah MI. http://lpmpjogja.org/.Diakses 5 Agustus 2015.

Alif Noor Hidayati 2015. Penjaminan Mutu di Satuan Pendidikan. http://lpmpjateng.go.id/ Akses 4 Agustus 2015.

Asep Suryana 2007. Akreditasi, Sertifikasi Dan Upaya Penjaminan Mutu Pendidikan. http://file.upi.edu/ Akses 4 Agustus 2015

Daeng Ayub Natuna. 2006. Metode Penelitian Kuantitatif. Pekanbaru: Departemen Pendidikan Nasional FKIP Universitas Riau.

Danang Dwi Yuhatmono. 2008. Pelaksanaan Manajemen Penjaminan Mutu Pendidikan Di SMK N 2 Depok. Jurnal. http://core.ac.uk/download/pdf/11059398.pdf. Akses Juni 2015.

Danny Meirawan. 2011. Manajemen Penjaminan Mutu Guru Studi Kasus di SMA Negeri 4 Malang. Skripsi, Jurusan Administrasi Pendidikan Fakultas Ilmu Pendidikan Universitas Negeri Malang. Akses Juni 2015.

Diklat Pengembangan Kapasitas SDM Penjaminan Mutu Pendidikan 2012.Konsep. egulasi. dan Kebijakan Penjaminan Mutu Pendidikan. Buku 1

Edi Satriadi. 2010. Efektivitas Implementasi Manajemen Strategik dalam Peningkatan Mutu Pendidikan Studi Kasus di Universitas Bung Hatta Padang Tahun 2004 s/d 2009.Akses Juni 2015.

Griffin. W. Ricky. Manajemen. Edisi 7. Jakarta. Erlangga. 2004.

Hariandja. Marihot Tua Efendi. Manajemen Sumber Daya Manusia. Jakarta. Grasindo. 2007.

Hadi Supriyatno. 2013. Studi Peningkatan Perah LPMP Dalam Pelaksanaan Sistem Penjaminan Mutu Pendidikan SPMP Melalui Pengembangan Sumber Daya Manusia Studi Kasus Pada LPMP Provinsi Kalimantan Timur. Universitas Pendidikan Indonesia repository.upi.edu perpustakaan.upi.edu. Akses Juni 2015.

Hariyanto. 2011. Penjaminan Mutu Pembelajaran pada Rintisan Sekolah Menengah Atas Bertaraf Internasional: Studi Multisitus di SMAN 3 Malang dan SMAN 5 Malang. Tesis. Program Studi Manajemen Pendidikan.

Harli Trisdiono 2015. Peran Widyaiswara Lembaga Penjaminan Mutu Pendidikan Dalam Peningkatan Kualitas Pendidikan Di Daerah. http://lpmpjogja.org/.Diakses 5 Agustus 2015.

Jam'an Satori 2010. Sistem Penjaminan Dan Peningkatan Mutu Pendidikan. Akses Juni 2015.

Kristina Setyowati. 2009. Strategi Pengembangan Sumber Daya Aparatur Berbasis Kompetensi. FISIP Universitas Sebelas Maret Surakarta. Jurnal Spirit Publik. Volume V Nomor 1.

Miles dan Huberman. 1992. Analisa Data Kualitatif. Jakarta: Universitas Indonesia.

Moleoung. J Lexy. 2009Metodologi Penelitian Kualitatif. Bandung: Remaja Rosda Karya.

Mulyasa. 2011. Manajemen Kepemimpinan Kepala Sekolah. Cetakana 1. Bumi Aksara. Jakarta.

Notoatmodjo. Soekidjo. 2009. Pengembangan Sumber Daya Manusia. Jakarta. Rineka Cipta. 2009.

Purwanto. 2010. Metode Penelitian Kuantitatif. Bandung: Remaja Rosda Karya

Resti Yuniarti. 2013. Pemanfaatan dan Pengembangan Sistem Teknologi Informasi di Lembaga Penjaminan Mutu Pendidikan.

http://sumberbelajar.belajar.kemdikbud.go.id. 5 Agustus 2015.

Ridlwan, M. 2009. Implementasi Sistem Penjaminan Mutu Layanan Akademik di Perguruan Tinggi Muhammadiyah Jawa Timur Studi Multisitus di Universitas Metropolis, Universitas Beachapolis, Universitas Agropolis. Disertasi, Program Studi Manajemen Pendidikan, Program Pascasarjana, Universitas Negeri Malang. Akses Juni 2015.

Prehallindo. Jakarta. 2001. Jilid I.

Syaiful Bahri Djamarah dan Aswan Zein. Strategi Belajar Mengajar. Jakarta: Rineka Cipta.2010.

Tommy Marsan. 2014. Kinerja Pengawas Sekolah Dasar Dalam Sistem Penjaminan Mutu Pendidikan Di Kota Metro Studi Kasus Pada Tiga Sekolah Dasar Di Kota Metro. Jurnal. Unila. http://digilib.unila.ac.id/3425/2/ABSTRAK.pdf. Akses Juni 2015.

Widya Study Sagala 2011. Manajemen Penjaminan Mutu Guru Studi Kasus di SMA Negeri 4 Malang. Skripsi. Jurusan Administrasi Pendidikan Fakultas Ilmu Pendidikan Universitas Negeri Malang. Akses Juni 2015.

Peraturan Menteri Pendidikan Nasional Nomor 7 Tahun 2007 Tentang Organisasi Dan Tata Kerja Lembaga Penjaminan Mutu Pendidikan.

Peraturan Menteri Pendidikan Nasional Nomor 63 Tahun 2009 Tentang Sistem Penjaminan Mutu Pendidikan. 